\title{
XRPD and SEM-EDS Identification of a Mineralogical Standards Kit Forming a 19th Century Collection for Educational Analysis
}

\author{
Emanuele Costa1, Alessandro Delmastro², Luca Di Gregorio3 ${ }^{3}$, Silvia Ronchetti², \\ Massimo Umberto Tomalino ${ }^{2}$ \\ ${ }^{1}$ Department of Earth Science, University of Turin, Torino, Italy \\ ${ }^{2}$ Department of Applied Science and Technology (DISAT), Polytechnic University of Turin, Torino, Italy \\ ${ }^{3}$ Former Department of Applied Science and Technology (DISAT), Polytechnic University of Turin, Torino, Italy \\ Email: emanuele.costa@unito.it
}

Received 21 December 2015; accepted 25 January 2016; published 28 January 2016

Copyright (C) 2016 by authors and Scientific Research Publishing Inc.

This work is licensed under the Creative Commons Attribution International License (CC BY).

http://creativecommons.org/licenses/by/4.0/

(c) (i) Open Access

\begin{abstract}
An historical collection of more than one hundred samples of minerals and ore, used in the second half of the XVIII century was found and acquired during Munich Mineralientage 2014. The samples contained in numbered glass vials but lacking description, were prepared for teaching purpose about determinative mineralogy and ore recognition. All samples were analysed and identified. The identification effort drove the authors along a historical excursus about the didactics of mineralogy and the dry method analysis, nowadays neglected.
\end{abstract}

\section{Keywords}

Blowpipe, XRPD, SEM-EDS, Historical Collection, Dry Analysis, Ore Identification

\section{Introduction}

During the 2014 edition of the most important European mineralogical exhibition-held in Munich every yearone of the authors, collector of mineralogical memorabilia, bought 19th century wooden box containing the 102 samples analysed in this study. The main objective of the acquisition and therefore of the present investigation has been the identification of each sample contained in its corresponding glass tube, as no historical list or label is anymore existing even if very probably it is, either for analytical or didactical purpose Figure 1 and Figure 2.

A didactical collection of old samples has been rarely analysed with modern methods and instrumentations

How to cite this paper: Costa, E., Delmastro, A., Gregorio, L.D., Ronchetti, S. and Tomalino, M.U. (2016) XRPD and SEM-EDS Identification of a Mineralogical Standards Kit Forming a $19^{\text {th }}$ Century Collection for Educational Analysis. Journal of Minerals and Materials Characterization and Engineering, 4, 73-86. http://dx.doi.org/10.4236/immce.2016.41008 


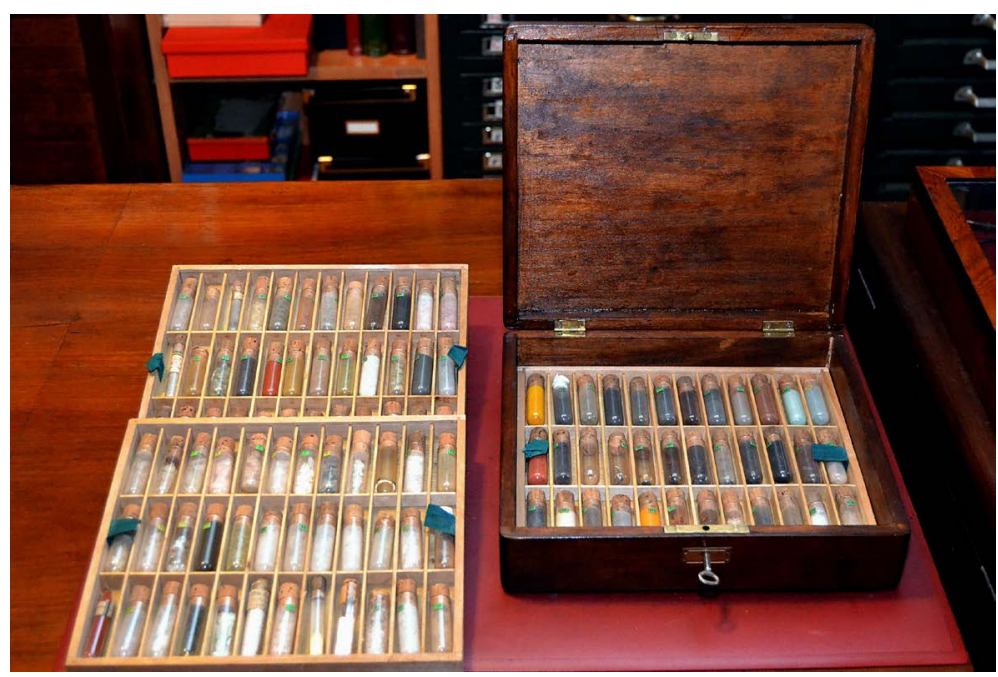

Figure 1. The wooden box with the three layered trays containing the probe-tube.

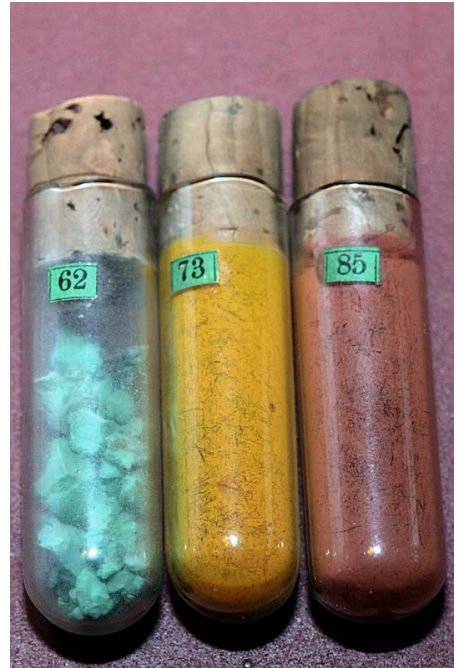

Figure 2. Three mineralogical samples.

and the results are of particular interest because they show what kind of mineral and substances are considered as industrial and scientific relevance at that time.

\section{Determination of Mineralogical Samples by Means of the Dry Analysis}

During the development of the industrial mineralogy, in the period starting from the late ' 700 to the beginning of the ' 900 , there was a strong need for chemists and geologists of easy, quick and reliable analytical methods. Their essential requirement was to guarantee an analytical accuracy in determining the presence of major or relevant elements in a mineral or in an ore rock, so that the industrial exploitation could be justified.

The classical analysis through dissolution, precipitation and weighing, although already well established at the middle of '800 (at least for the most important elements) was a long, annoying and time consuming way to obtain chemical information about the composition of a generic mineralogical sample or of a specific ore sample, that is a mineral or an aggregate of minerals from which a valuable constituent, especially a metal, can be profitably mined or extracted. It needed a well-equipped laboratory, a number of chemical substances and a skilled chemist. All these conditions collided with the needs of obtaining, directly during the field search and in a short time, the information needed to prepare suitably the mining work and focus the research on the different field areas. 
In order to satisfy the above request, different methods of analysis, which require no or little chemical manipulations, a minimal use of chemicals and laboratory tools, and only a simple training were developed. The most of them are practically using no water or acid for dissolution (and consequently no or very little glassware, as it is always problematic to be used in the field) and for this reason are called dry analysis methods. Essentially, these methods consist in observing the eventual modifications, reactions and transformations of the sample once heated, melted with simple chemicals, or placed in a flame.

The main methods are listed as follows:

-Heating on a platinum foil: the analyst could observe combustion (organic substance), possible formation of residual deposits, developing of volatile substances (some of them recognizable by their smell), fusion or resistance to heat. All of these characteristics could orient the researcher to different ways.

-Heating in close test tube: the observation of a small amount of unknown ore or mineral placed in a small test tube, heated on the base, can give useful information about the presence of water (condensation of droplets in the cold zone of the tube), sulphides (condensation of sulphur or developing of $\mathrm{SO}_{2}$ or $\mathrm{H}_{2} \mathrm{~S}$ ) and so on. The release of carbon monoxide-burning with blue flame at the top of the tube-can reveal the presence of formiate or oxalate groups. The release of red vapour of nitrous oxide suggests the presence of nitrates, whereas the ammonia smell suggests the presence of ammonia salts or nitrogen bearing organic substances.

Different sublimates can be deposited near the edge of the tube, such as red mercuric sulphide, or orange arsenic sulphide, thereby suggesting the presence of such so important industrial elements like mercury or arsenic.

-Heating in an open test tube: a small test tube, shaped as wide opened "U" arms, with a small amount of the sample placed in the lower part of the tube, is heated in a flame. Differently than the previous test, the air flowing in the tube from the open side can produce an oxidation of the unknown mineral developing different substances compared with those of the previous method.

-Heating on coal: a small amount of the substance, placed in a small pit carved in a coal brick, is heated directly by blowing the dart of a flame on it. The reaction with the coal can release small droplets or globules of reduced metals, such as lead, tin, zinc, bismuth, but also, in some cases, gold and silver, in revealing the interest for a mineral exploitation. Aside of these fortunate events, also the developing of a white or coloured halo on the coal can suggest the presence of some metals, and the variation of this method (heating in an oxidative or reductive flame and mixing with sodium carbonate) gives a lot of information to the chemist. In adopting such a method it would be very useful the use of an instrument called blowpipe.

-Flame test: this well know test even nowadays is based on the coloration assumed by the flame of a alcohol lamp (or better, if available on the field, a Bunsen lamp) which would reveal the presence of many different metals like copper, lithium, barium, potassium and so on. A skilled chemist can also notice the different colour obtained by using the substance as it is, or wetted with hydrochloric or nitric acid.

-Borate and phosphate pearls: this method also practiced by modern chemists, consists in obtaining a coloration in a vitreous mass of sodium borate or sodium ammonium phosphate (phosphate salt); it is a useful tool to suggest the presence of some metals in a substance. A small amount, sometimes a single grain of unknown substance is mixed with sodium borate (or phosphate salt), and heated until fusion. The developed colour, the difference of colour between the hot and the cold pearl, the tinge difference in oxidative or reductive flame are the distinctive features that could drive a chemist to the identify a specific metal in a mineral.

These are only the most important ways to test a substance without (or reducing to a very minimal amount) the use of acid, base and chemicals. Almost all these methods drive only to the identification of the metallic or semi-metallic element contained in an ore, because metals were (and still are) the base of the modern industry, and except in rare occasions, no relevance must be given to the oxidation state and/or to the coordination number of the metal within the crystal lattice. For example, there is no reason to know if chromium is in its trivalent or hexavalent form, or if copper carbonate is azurite or malachite. However, even if these methods of analysis look like quite simple, a training of the chemist or mineralogist is necessary. This is the reason why in the past many analytical kits producers organized didactical collections, containing samples of the most commons minerals, particularly interesting for the industrial exploitations.

\section{Blowpipe Analysis: An Historical Overview}

In the modern day education of mineralogists and chemists, the study of blowpipe analysis becomes only a historical curiosity. On the other hand, by using this technique from the end of the 18th century to the middle of the 
19th century, the qualitative composition of most minerals was identified and contributed to the discovery of over 15 elements [1].

In 1862, the German mineralogist Franz von Kobell (1803-1882) described the blowpipe as an instrument that "in its way, served chemical mineralogy as much as the goniometer served crystallography" [2]. In fact, the blowpipe was one of the most important analytical tools for identifying metallic elements by their different physical reactions like fusibility or colour change. The instrument consists of a small tube (more or less sophisticated in the various, advanced versions), an extremity of which was held in the mouth by the chemist, that gently blows a whisper of air in the flame through the other end, that was placed near, inside or at the middle of the flame itself. The air blow creates a so-called dart, directed with ability and skill on the substance (Figure 3). The different position in the flame generated an oxygen-rich or reductive environment, so modifying the reaction of the mineral. Old books [i.e. Bergman, Berzelius] devoted to this kind of analysis suggest the use of a candle flame, or an alcohol lamp flame, both inexpensive and easy to use in the field as well.

The reaction in the oxidizing or reducing zone of the flame can be easily observed with charcoal, clay, glass or platinum serving as a support. The sample, submitted to various tests with the blowpipe, can be analysed with the addition of fluxes and reagents. Most metals can be identified through the coloration of the flame. Much experience and talent is necessary for an efficient work with the blowpipe. Complicated modifications to the original blowpipe design were applied sometimes even including the use of oxygen or hydrogen to obtain the highest temperatures. The origin of the blowpipe is lost in antiquity but was probably an invention of the Egyptians whose goldsmiths were familiar with the use of metallic blowpipes as shown on wall tomb paintings dated around 2400 B.C. However, the very first description of a blowpipe experiment conducted on a fossil sample is due to the English physicist Robert Hooke (1635-1703). The Danish physician Erasmus Bartholin (1625-1698), in his famous work of 1669 , not only was the first to recognize the crystal optics but was also the first to perform experiments in the field of crystal chemistry by decomposing a crystal of Iceland spar into lime by means of a blowpipe [3]. The best mine assayer and metallurgist of his time, the German Johann Andreas Cramer (17101777), recommended that a small quantity of ore be fused with borax on charcoal support. He first described in detail a copper blowpipe with a hollow ball to collect the saliva [4].

Particularly in Sweden the blowpipe was used by mineralogists and metallurgists for quick qualitative tests of ores, while in Germany at a later period, a school of blowpipe technique gradually evolved so that the teachers passed on their knowledge to their assistants. Among them, Andreas von Swab was the first to start using constantly the blowpipe for mineral analysis about the year 1738 [5]. Belonging to the same school, the chemist Carl Wilhelm Scheele (1742-1786) made experiments in which he first could discover the elements manganese, chlorine, barium, tungsten and molybdenum: he wrote that the inner flame of the blowpipe contains more phlogiston (oxygen) than outer and furthermore he recognized the reducing and the oxidizing zones of the flame. Meanwhile Axel Friedrich Cronstedt (1722-1765) was a first-rate mining expert and appointed director of all mines of Sweden in 1748 [6]. He employed soda and borax as fluxes and learnt how to use phosphorous salts in the quantitative analysis of characteristically coloured metallic oxides. In 1756, he examined minerals from Iceland and Lapland by discovering the existence of the important group of minerals called zeolites, a word de-

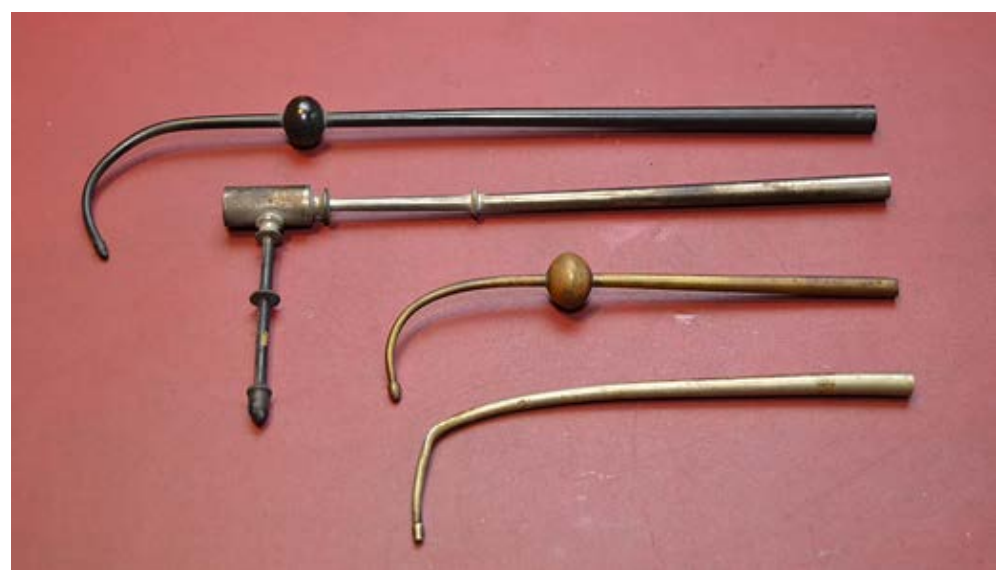

Figure 3. Some historical blowpipes. 
rived from Greek meaning to effervesce. In 1770, Gustav von Engestrom (1738-1813) published very clear and illustrated instructions for the use of the blowpipe. This talented chemist invented not only a blowpipe, but also various other items for blowpipe experiments which all fit into a neat, small box which could comfortably be carried in a pocket—especially on travels—so that it could be called a pocket laboratory [7].

The Swedish chemical genius Torbern Olof Bergman (1735-1784) published many articles and treatises mentioning blowpipe experiments in passing. These were not limited to minerals but also extended into the fields of mineral waters and organic matter. In his main work of 1779, a modified 3-piece blowpipe made out of silver was described. In addition to charcoal, he also used a silver or gold spoon as a sample support; his portable kit also included an anvil, a hammer, some specimen pliers and a candle holder [8].

Bergman's most important student was Johann Gottlieb Gahn (1745-1818), who became his assistant at the chemical institute of Uppsala after 1767. Later he built his own laboratory in the mining town of Falun and became an unsurpassed master in the art of blowpipe analysis.

Jons Jakob Berzelius (1779-1848) was probably the most famous of the Swedish chemists. In 1803, he discovered cerium and later thorium and selenium (Bergman, 1779). Even if at his times he became famous for the blowpipe technique, he is the inventor of the chemical symbols in common use today and he proved the law of constant proportions. Also thanks to the invention of many types of laboratory equipment, he transformed the alchemical cellar into a modern laboratory. Among the many innovations, Berzelius introduced the practise of the analytical separation by using hydrogen sulphide to precipitate metallic sulphides, later on tested by means of the blowpipe. In his classic book of 1821, all aspects of the blowpipe analysis were clearly summarized and several different types of blowpipes as well as a special oil lamp designed by him are described in detail. In such a way, he was able to distinguish the four zones of the flame and used the key-words oxidation and reduction in this context [9].

Later on Edward Turner (1798-1837), a chemist, was one of the first to use the coloration of the flame as a diagnostic mean. He developed a technology to prove the existence of lithium in hardly fusible mineral species [10]. A mixture of the powdered sample was fused with fluorite and ammonium sulphate whereby a characteristic red colour of the blowpipe flame could be observed.

The "Pope" of the blowpipe analysis was the German chemist Karl Friedrich Plattner (1800-1858) who studied in the Mining Academy of Freiberg and invented new procedures for quantitative blowpipe analysis for gold, copper, lead, tin and (at a later stage) for nickel, cobalt and bismuth [11]. He augmented the methods by adding wet chemical tests in combination with blowpipe experiments. Coming from the same school of Freiberg, Hyeronimus Theodor Richter (1824-1898) was appointed director of the Mining Academy in 1875 and by means of the blowpipe's methodology was able to discover the element thallium and indium from his studies on the mineral sphalerite. The blowpipe played an important role in the discovery of a new element for the last time in 1885 when Richter analysed a mineral sample of Argyrodite, which contains Germanium: the so-called ekasilicium, predicted by Mendeleev was therefore found and the validity of his Periodic table of the Elements was finally proven. At the end of his work, Richter also referred to some of the few extensions of the use of the blowpipe beyond the borders of mineralogy into the recognition and testing of organic substances.

In 1837, the above-mentioned Franz von Kobell proposed-in analogy to the well-known Mohs' hardness scale-a six-step fusibility scale and demonstrated how close-looking the mineral species could be differentiated by its application: he suggested that samples of the minerals in this scale should always be kept handy for comparative purposes.

The decline of the blowpipe began with the invention of gas burner by Robert Wilhelm Bunsen (1811-1899). Such an equipment was able to reach temperatures of more than $2300^{\circ} \mathrm{C}$ and the research focused on the experiments with the indicative coloration that molten substances imparted to the flame [12]. He also developed the diagnostic methods for the determination of sodium in the presence of potassium and for better differentiating them he used a cobalt glass. A hollow prism filled with a solution of indigo allowed him to recognize the flame coloration of lithium in the presence of sodium and potassium. Bunsen's observations with the blowpipe and gas burner prompted him, in cooperation with Gustav Robert Kirchoff (1824-1887) to develop the spectral analysis in 1859. Flame spectroscopy and later absorption spectroscopy revolutionized chemical analysis and the chemical detection improved dramatically. With the aid of the spectral analysis, Bunsen discovered the two new elements caesium and rubidium [13] [14].

The 1912 discovery by Max von Laue (1879-1957) of diffraction of the X-rays passing through a crystal established the possibility of relating crystal structure to the chemical composition of a mineral. This new, revolu- 
tionary method delivered the end to the use of the blowpipe, which had played such an important role during the century from ca. 1760 to 1860 .

\section{Materials and Methods}

A multidisciplinary approach has been focused on studying the old samples. First, an elementary analysis has been accomplished by using a SEM-EDS, in order to identify the main constituents of the mineral phases. Subsequently, a XRPD identification has been carried out, by reducing the compositional range of the suitable mineral phases to what suggested by EDS.

The first check has been done by means of a SEM Stereoscan 360 (Cambridge Instrument), coupled with an EDS Link Pentafet (Oxford Instrument) equipped with a "thin window" detector, allowing qualitative/quantitative chemical analysis of light elements (down to carbon). Working parameters are as follows: acceleration voltage $15 \mathrm{kV}$, working distance $25 \mathrm{~mm}$, probe current $1 \mathrm{nA}$ and spectra acquisition time varying from 60 to 300 s. Daily standardization has been performed by using a pure Co specimen. Chemical data have been collected on coated carbon fragments of the samples, processed with the Inca 200 Microanalysis Suite Software, version 4.08 with main calibration on natural mineral standards by using the ZAF correction method. The instrument could not recognize hydrogen, lithium, beryllium and boron, therefore the presence of these elements has been often supposed during the following analytical step. The analysis, normally performed on unpolished samples, has been considered only as semi-quantitative and approximate.

XRPD characterization has been carried out on crushed sample using a Panalytical X'Pert PRO (Cu $\mathrm{K}_{\alpha}$ radiation) diffractometer, with a PIXcel detector, a solid-state detector with rapid readout time and high dynamic range. Data collection has been performed between $5^{\circ}$ and $90^{\circ} 2 \theta$, with a step of $0.02^{\circ} 2 \theta$. ICDD-PDF database has been used to interpret powder diffraction patterns.

\section{Results and Discussion}

The main goal (the identification of the mineral species contained in the historical wooden box) has been achieved with a high degree of confidence. Most identified minerals were interesting for industrial or technological purpose, as it can happen to a collection assembled on the behalf of teachers of quick mineralogical analysis and practical application.

A certain order in the distribution of the samples has been noticed: with some exception, the original sequence of numbers labelled on the tubes follows a chemical periodic order. At the beginning there are the mineralogical species containing cations of the first group ( $\mathrm{Li}, \mathrm{Na}, \mathrm{K}$ and even ammonium). Then there are the samples containing the second group elements ( $\mathrm{Be}, \mathrm{Mg}, \mathrm{Ca}, \mathrm{Sr}$ and $\mathrm{Ba}$ ). Afterwards, there is a group containing the most common transition metals ( $\mathrm{Mn}, \mathrm{Zn}, \mathrm{Fe}, \mathrm{Ni}, \mathrm{Co}, \mathrm{Pb}, \mathrm{Cr}, \mathrm{Sn}, \mathrm{Cu}$ and $\mathrm{Ag}$ ) in many cases as carbonate, oxide, sulphide, arsenide or antimonide, rarely as native element (like silver and arsenic, Figure 4). The mutual usage of both techniques has been fundamental either as the EDS, although necessary for screening the elements, is not able to detect some of them like B and Be, or as it can't distinguish among the different polymorphous phases.

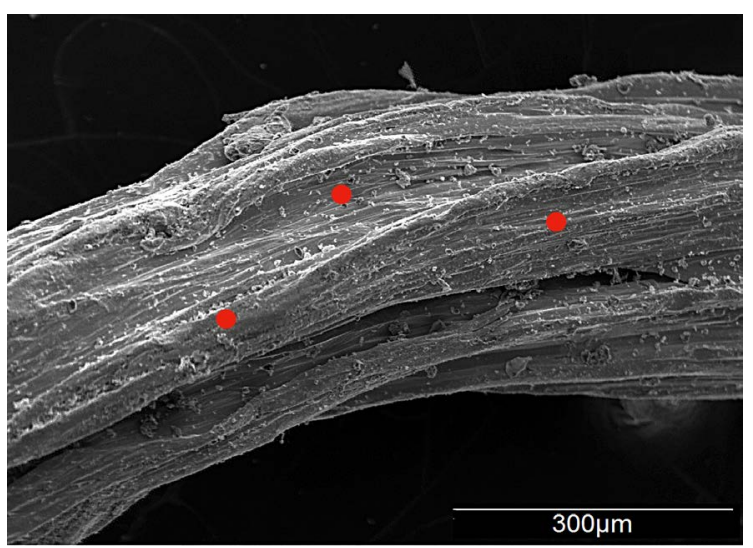

Figure 4. SEM image of native silver (sample n. 88). The red spots indicate the position of EDS analysis on the sample. 
Uranium and REE belong to this group as well. The next group includes partly mixed and strictly correlated rarer species containing unusual or less useful—for that epoch! —elements (niobium, titanium, tungsten and molybdenum). The series of samples, besides some common silicates, finish with some organic substances as beeswax and amber, probably used to show the reactions of organics under the dry analysis (to be noticed the choice of the former, very fusible, and the latter almost infusible), and of a very fusible inorganic material (boric acid).

The last sample is quartz, one of the best examples of simple mineral without perceivable cations, and almost impossible to melt. On the opposite, the diffractometric technique allows a certain identification of each phase (Figure 5(a) and Figure 5(b)).

It is remarkable to notice that many of the samples are real ore fragments, containing different silicates as mother rocks or containing two or even three different species of the same cation, as it could be expected to be found during the normal field activity. The analytical work on the samples of the present study have allowed to identify the mineralogical species which were strategic from the industrial point of view of the time and interesting for representing the chemical reference terms. All the samples have been surely identified (Table 1).

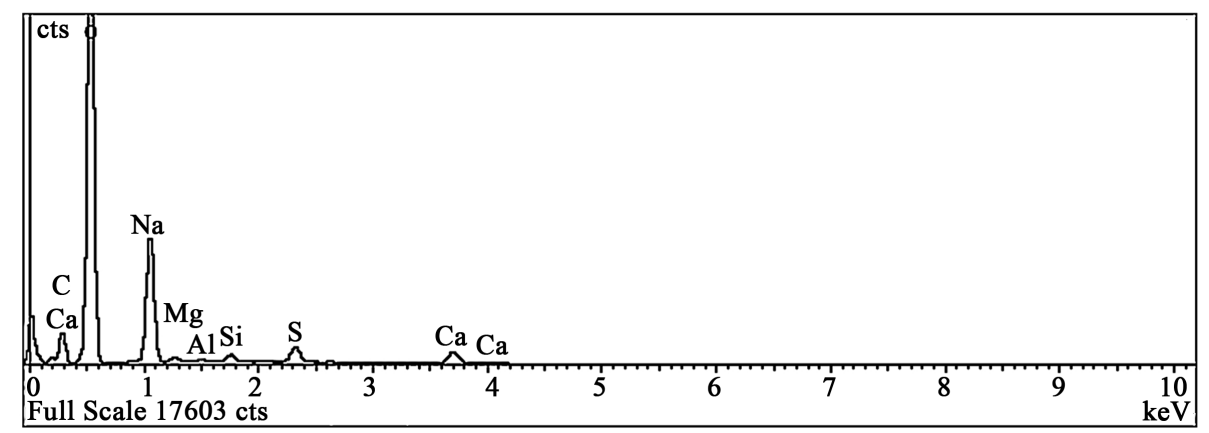

(a)

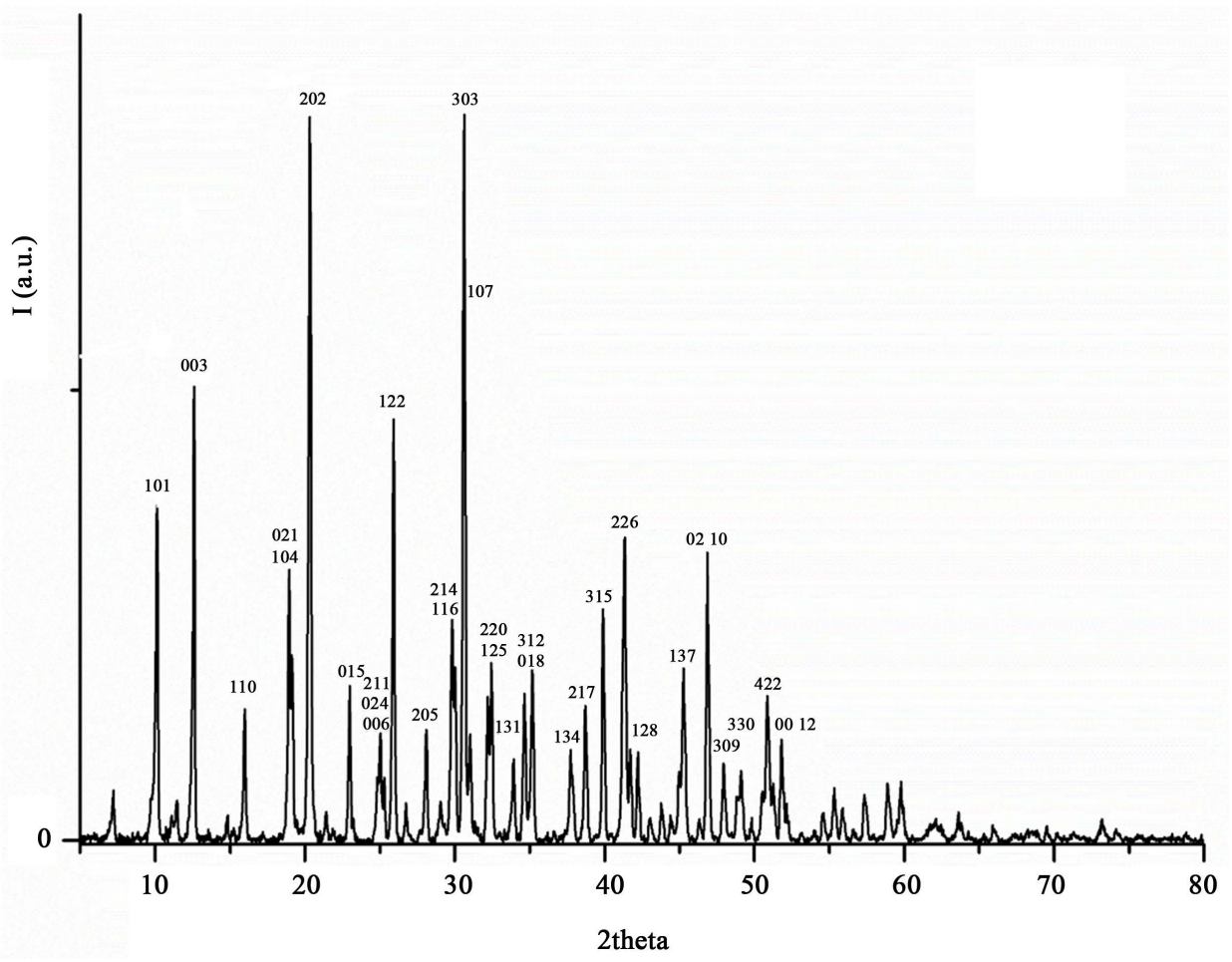

(b)

Figure 5. (a) EDS spectrum of sample n. 11 showing the main peaks of $\mathrm{C}, \mathrm{O}$ and $\mathrm{Na}$, simulating a carbonate, (b) the XRPD of the same sample clearly identifies Tincalconite (ICDD-PDF 07-0277). 
Table 1. Identification data of the samples. Samples 10, 25, 30 and 65 are missing.

1 White crystalline powder

Oxygen, sulfur, aluminum and nitrogen

White crystalline powder,

2 traces of natural plane

faces and "cubic" aspect

3

White crystalline powder, no traces of cleavage

White crystalline powder, traces of cleavage and/or flat faces

$5 \quad$ White smooth powder

$6 \quad$ White granules

7 White crystalline fragments

8

White crystalline fragments

9

White crystalline powder

Missing sample

11

White powder

Pale yellow crystalline

12

powder, some fragments with cleavage

Pale whitish-yellowish fragments

14

Withe powder

15 White powder

16 White crystalline powder

17

Greenish-blackish fragments
Potassium and chlorine

Silicon, potassium, aluminum and oxygen

Calcium, silicon, oxygen, fluorine, minor sodium and iron

Oxygen, sulfur, sodium, potassium, calcium

Fluorine, sodium and aluminum

Oxygen, silicon, aluminum, sodium and minor amount of potassium

Oxygen, silicon,

aluminum, calcium, sodium and minor potassium

Oxygen, aluminum, sodium, silicon, small amount of calcium

Oxygen, sodium and minor amount of magnesium, sulfur and chlorine

Oxygen, phosphor, iron and manganese

Aluminum, silicon, oxygen

Aluminum, silicon, oxygen

Aluminum, silicon, iron, manganese, potassium and fluorine

Aluminum, silicon, oxygen, manganese

Oxygen, magnesium, silicon, calcium, iron and lesser amount of aluminum and chromium
Ammonium aluminum sulfate hydrate

ICDD PDF 83-1933

Sylvite

ICDD PDF 41-1476

Potassium feldspar

(Adularia)

ICDD PDF 71-1543

Fluorapophillite

ICDD PDF 71-1778

Sodium nitrate

ICDD PDF 89-2828

sodium potassium sulfate

ICDD PDF 74-0394

Cryolite

ICDD PDF 25-0772

Albite

ICDD PDF 89-6423

Albite

ICDD PDF 89-1939

Natrolite

ICDD PDF 45-1413

Tincalconite

ICDD PDF 07-0277

Lithiophilite

ICDD PDF 13-0336

Spodumene

ICDD PDF 71-1063

Petalite

ICDD PDF 35-0463

Muscovite

(fluor-muscovite) and/or

celadonite

ICDD PDF 49-1840

Lithiophorite

ICDD PDF 41-1371

Magnesium-hornblende

ICDD PDF 20-0481
Ammonium aluminum sulfate, dodecahydrate

$\left(\mathrm{NH}_{4}\right) \mathrm{Al}\left(\mathrm{SO}_{4}\right)_{2} \cdot 12 \mathrm{H}_{2} \mathrm{O}$

The material, apparently synthetic, belongs to the collection probably to show the reactions of a very hydrate and heat-reacting substance

Sylvite, $\mathrm{KCl}$

Could be either of natural or synthetic origin

Adularia, $\mathrm{KAlSi}_{3} \mathrm{O}_{8}$

Fluorapophillite

$\mathrm{KCa}_{4}\left(\mathrm{Si}_{4} \mathrm{O}_{10}\right)_{2}\left(\mathrm{~F}_{0.5} \mathrm{OH}_{0.5}\right)\left(\mathrm{H}_{2} \mathrm{O}\right)_{8}$

Mixing of laboratory chemicals, mainly potassium nitrate $\left(\mathrm{KNO}_{3}\right)$ and sodium potassium sulfate $\left(\mathrm{KNaSO}_{4}\right)$ Probably synthetic, could have been included to show the reaction of nitrates and sulfates of alkali elements.

Cryolite, $\mathrm{Na}_{3} \mathrm{AlF}_{6}$

Albite, $\mathrm{NaAlSi}_{3} \mathrm{O}_{8}$ A plagioclase very close to albite composition

Albite, $\mathrm{NaAlSi}_{3} \mathrm{O}_{8}$ A plagioclase in the range of the albite-oligoclase composition

Natrolite, $\mathrm{Na}_{2} \mathrm{Al}_{2} \mathrm{Si}_{3} \mathrm{O}_{10} \cdot 2 \mathrm{H}_{2} \mathrm{O}$

Borax or tincalconite $\mathrm{Na}_{2}\left(\mathrm{~B}_{4} \mathrm{O}_{5}(\mathrm{OH})_{4}\right)\left(\mathrm{H}_{2} \mathrm{O}\right)_{2.668}$ It was probably Borax, but the long time altered it in a derivative

of borax, Tincalconite.

Triphylite, $\mathrm{Li}(\mathrm{Mn}, \mathrm{Fe}) \mathrm{PO}_{4}$ A sample of the Lithiofilite (Mn) and

Triphylite (Fe) series, close to the

Triphylite because of the iron content.

Spodumene, $\mathrm{LiAlSi}_{2} \mathrm{O}_{6}$

Petalite, $\mathrm{LiAlSi}_{4} \mathrm{O}_{10}$

\section{Muscovite-Phlogopite series}

Lithiophorite, $(\mathrm{Al}, \mathrm{Li}) \mathrm{MnO}_{2}(\mathrm{OH})_{2}$ A mixture of Lithiophorite and Quartz

Magnesio-hornblende $(\mathrm{Ca}, \mathrm{Na})_{2}{ }^{-}(\mathrm{Mg}, \mathrm{Fe}, \mathrm{Al})_{5}(\mathrm{Si}, \mathrm{Al})_{8} \mathrm{O}_{22}(\mathrm{OH})_{2}$ 


\section{Continued}

\begin{tabular}{|c|c|c|c|c|}
\hline 18 & White crystalline powder & $\begin{array}{l}\text { Carbon, oxygen, } \\
\text { barium }\end{array}$ & $\begin{array}{c}\text { Witherite } \\
\text { ICDD PDF 71-2394 }\end{array}$ & Witherite, $\mathrm{BaCO}_{3}$ \\
\hline 19 & White crystalline powder & $\begin{array}{l}\text { Carbon, oxygen, } \\
\text { barium, calcium }\end{array}$ & $\begin{array}{c}\text { Cobaltocalcite } \\
\text { ICDD PDF 15-0285 }\end{array}$ & Baritocalcite, $\mathrm{BaCa}\left(\mathrm{CO}_{3}\right)_{2}$ \\
\hline 20 & White crystalline powder & $\begin{array}{l}\text { Strontium, } \\
\text { oxygen, sulfur }\end{array}$ & $\begin{array}{c}\text { Celestine } \\
\text { ICDD PDF 05-0593 }\end{array}$ & Celestine, $\mathrm{SrSO}_{4}$ \\
\hline 21 & White crystalline powder & $\begin{array}{l}\text { Strontium, oxygen, car- } \\
\text { bon }\end{array}$ & $\begin{array}{c}\text { Strontianite } \\
\text { ICDD PDF 71-2393 }\end{array}$ & Strontianite, $\mathrm{SrCO}_{3}$ \\
\hline 22 & $\begin{array}{l}\text { White crystalline powder } \\
\text { with traces of cleavage }\end{array}$ & Fluorine and calcium & $\begin{array}{c}\text { Fluorite } \\
\text { ICDD PDF 70-1469 }\end{array}$ & Fluorite, $\mathrm{CaF}_{2}$ \\
\hline 23 & White fine powder & $\begin{array}{l}\text { Calcium, oxygen } \\
\text { and sulfur }\end{array}$ & $\begin{array}{c}\text { Gypsum } \\
\text { ICDD PDF 70-1469 }\end{array}$ & Gypsum, $\mathrm{CaSO}_{4} \cdot 2 \mathrm{H}_{2} \mathrm{O}$ \\
\hline 24 & $\begin{array}{l}\text { Glassy yellowish and } \\
\text { bluish fragments, } \\
\text { conchoidal fracture }\end{array}$ & $\begin{array}{l}\text { Phosphor, oxygen, } \\
\text { calcium, fluorine, a small } \\
\text { amount of chlorine }\end{array}$ & $\begin{array}{c}\text { Fluoroapatite } \\
\text { ICDD PDF 71-0880 }\end{array}$ & Fluorapatite, $\mathrm{Ca}_{5}\left(\mathrm{PO}_{4}\right)_{3} \mathrm{~F}$ \\
\hline 25 & Missing sample & & & \\
\hline 26 & White crystalline powder & $\begin{array}{l}\text { Calcium, carbon, } \\
\text { oxygen with minor } \\
\text { amount of magnesium }\end{array}$ & $\begin{array}{c}\text { Calcite } \\
\text { ICDD PDF 89-1304 }\end{array}$ & $\begin{array}{c}\text { Calcite, } \mathrm{CaCO}_{3} \\
\text { Composition is very close to pure calcite, } \\
\text { with only } 0.03 \% \mathrm{~m} / \mathrm{m} \text { of magnesium }\end{array}$ \\
\hline 27 & White crystalline fragments & $\begin{array}{l}\text { Silicon, calcium and } \\
\text { oxygen, with minor } \\
\text { iron and chromium }\end{array}$ & $\begin{array}{c}\text { Wollastonite } \\
\text { ICDD PDF 42-0547 }\end{array}$ & Wollastonite, $\mathrm{CaSiO}_{3}$ \\
\hline 28 & Green crystalline fragments & $\begin{array}{l}\text { Silicon, calcium, } \\
\text { aluminum, iron and } \\
\text { oxygen, with minor } \\
\text { amount of sodium }\end{array}$ & $\begin{array}{c}\text { Clinozoisite } \\
\text { ICDD PDF 71-1539 }\end{array}$ & $\begin{array}{l}\text { Epidote, } \mathrm{Ca}_{2}(\mathrm{Fe}, \mathrm{Al})_{3}\left(\mathrm{SiO}_{4}\right)_{3}(\mathrm{OH}) \\
\text { The sample is a mixed member } \\
\text { of the series Clinozoisite-Epidote }\end{array}$ \\
\hline 29 & White greenish scales & $\begin{array}{l}\text { Magnesium, silicon, } \\
\text { oxygen and minor iron }\end{array}$ & $\begin{array}{c}\text { Talc } \\
\text { ICDD PDF 29-1493 }\end{array}$ & Talc, $\mathrm{Mg}_{3} \mathrm{Si}_{4} \mathrm{O}_{10}(\mathrm{OH})_{2}$ \\
\hline 30 & Missing sample & & & \\
\hline 31 & Creamy-white powder & $\begin{array}{l}\text { Calcium, carbon, oxygen } \\
\text { and little amount of iron } \\
\text { and manganese }\end{array}$ & $\begin{array}{l}\text { Ferroan Dolomite } \\
\text { ICDD PDF 41-0586 }\end{array}$ & $\begin{array}{l}\text { Ferroan Dolomite, } \mathrm{Ca}(\mathrm{Fe}, \mathrm{Mg}, \mathrm{Mn})\left(\mathrm{CO}_{3}\right)_{2} \\
\text { Magnesium in dolomite is often replaced } \\
\text { by a small amount of iron and manganese }\end{array}$ \\
\hline 32 & Whitish powder & Carbon and oxygen & $\begin{array}{l}\text { Phenolphthalein } \\
\text { ICDD PDF 51-2358 }\end{array}$ & $\begin{array}{l}\text { Phenolphthalein, } \mathrm{C}_{20} \mathrm{H}_{14} \mathrm{O}_{4} \\
\text { Phenolphthalein is an organic } \mathrm{pH} \text {-indicator that } \\
\text { does not match with minerals. Probably it was } \\
\text { used as a replacement of a consumed sample }\end{array}$ \\
\hline 33 & White powder & $\begin{array}{l}\text { Manganese, } \\
\text { sulfur, oxygen }\end{array}$ & $\begin{array}{c}\text { Manganese } \\
\text { sulfate hydrate } \\
\text { ICDD PDF 33-0906 }\end{array}$ & $\begin{array}{l}\text { Manganese sulfate monohydrate } \\
\qquad \mathrm{MnSO}_{4} \cdot \mathrm{H}_{2} \mathrm{O} \\
\text { May be a laboratory product }\end{array}$ \\
\hline 34 & White powder & $\begin{array}{l}\text { Sodium, sulfur, } \\
\text { magnesium, oxygen }\end{array}$ & $\begin{array}{l}\text { Magnesium sulfate hydrate } \\
\text { and sodium magnesium } \\
\text { sulfate hydrate } \\
\text { ICDD PDF 72-1068 } \\
\text { ICDD PDF 71-0307 }\end{array}$ & $\begin{array}{c}\text { Magnesium sulfate hydrate } \mathrm{MgSO}_{4} \cdot 6 \mathrm{H}_{2} \mathrm{O} \\
\text { Sodium magnesium sulfate hydrate } \\
\mathrm{Na}_{2} \mathrm{Mg}\left(\mathrm{SO}_{4}\right)_{2} \cdot 4 \mathrm{H}_{2} \mathrm{O} \\
\text { May be either a natural mineral } \\
\text { or a laboratory product. }\end{array}$ \\
\hline 35 & White crystalline powder & $\begin{array}{l}\text { Aluminum, sulfur, } \\
\text { potassium and oxygen }\end{array}$ & $\begin{array}{c}\text { Alunite } \\
\text { ICDD PDF 73-1652 }\end{array}$ & $\begin{array}{l}\text { Alunite, } \mathrm{K}\left(\mathrm{Al}_{3}(\mathrm{OH})_{6}\left(\mathrm{SO}_{4}\right)_{2}\right. \\
\text { May be either a natural mineral } \\
\text { or a laboratory product. }\end{array}$ \\
\hline 36 & $\begin{array}{l}\text { Crystalline fragments, } \\
\text { colorless, traces of natural } \\
\text { faces, conchoidal fracture }\end{array}$ & $\begin{array}{l}\text { Silicon, oxygen, } \\
\text { aluminum and fluorine }\end{array}$ & $\begin{array}{l}\text { Topaz, aluminum } \\
\text { fluosilicate. } \\
\text { ICDD PDF 12-0765 }\end{array}$ & Topaz, $\mathrm{Al}_{2} \mathrm{SiO}_{4}(\mathrm{~F}, \mathrm{OH})_{2}$ \\
\hline 37 & $\begin{array}{l}\text { Greyish fragments without } \\
\text { particular features }\end{array}$ & $\begin{array}{l}\text { Aluminum and oxygen } \\
\text { with some impurities }\end{array}$ & $\begin{array}{c}\text { Chrysoberyl } \\
\text { ICDD PDF 78-0958 }\end{array}$ & $\begin{array}{c}\text { Chrysoberyl, } \mathrm{Al}_{2} \mathrm{BeO}_{4} \\
\text { EDS did not determine the presence } \\
\text { of beryllium, due to its low atomic mass }\end{array}$ \\
\hline 38 & $\begin{array}{l}\text { Hyaline yellowish } \\
\text { fragments }\end{array}$ & Aluminum and oxygen & $\begin{array}{c}\text { Corundum } \\
\text { ICDD PDF 81-2267 }\end{array}$ & Corundum, $\mathrm{Al}_{2} \mathrm{O}_{3}$ \\
\hline 39 & $\begin{array}{l}\text { A white-grayish } \\
\text { powder of metallic } \\
\text { appearance }\end{array}$ & $\begin{array}{c}\text { Aluminum and oxygen } \\
\text { with impurities } \\
\text { of copper and iron }\end{array}$ & $\begin{array}{c}\text { Aluminum } \\
\text { ICDD PDF 04-0787 }\end{array}$ & $\begin{array}{l}\text { Aluminum, } \mathrm{Al} \\
\text { Impurities of } \mathrm{Cu} \text { and } \mathrm{Fe} \\
\text { in the powder }\end{array}$ \\
\hline
\end{tabular}




\section{Continued}

\begin{tabular}{|c|c|c|c|c|}
\hline 40 & $\begin{array}{l}\text { White porcelanaceous } \\
\text { fragments, } \\
\text { conchoidal fracture. }\end{array}$ & $\begin{array}{l}\text { Silicon, aluminum and } \\
\text { oxygen }\end{array}$ & $\begin{array}{c}\text { Beryl } \\
\text { ICDD PDF 84-1141 }\end{array}$ & $\begin{array}{c}\text { Beryl, } \mathrm{Be}_{3} \mathrm{Al}_{2} \mathrm{Si}_{6} \mathrm{O}_{18} \\
\text { EDS did not determine the presence } \\
\text { of beryllium, due to its low atomic mass }\end{array}$ \\
\hline 41 & $\begin{array}{l}\text { Dark, blackish } \\
\text { fragments with } \\
\text { conchoidal fractures }\end{array}$ & $\begin{array}{l}\text { Oxygen, aluminum, } \\
\text { calcium, iron and silicon, } \\
\text { REE elements } \\
\text { (La, Ce, Nd) }\end{array}$ & $\begin{array}{l}\text { The spectrum is } \\
\text { probably matching } \\
\text { the Allanite's one }\end{array}$ & $\begin{array}{c}\text { Allanite (epidote group) } \\
(\mathrm{Ca}, \mathrm{REE})_{2}(\mathrm{Fe}, \mathrm{Al})_{3}\left(\mathrm{SiO}_{4}\right)_{3}(\mathrm{OH}) \\
\text { XRPD spectrum shows a low crystallinity, } \\
\text { probably due to a radiation damage } \\
\text { (metamictization) of the crystalline structure }\end{array}$ \\
\hline 42 & $\begin{array}{l}\text { Yellow and dark yellow } \\
\text { fragments, no cleavage, } \\
\text { conchoidal fracture }\end{array}$ & $\begin{array}{l}\text { Oxygen, silicon and } \\
\text { zirconium }\end{array}$ & $\begin{array}{c}\text { Zircon } \\
\text { ICDD PDF 83-1375 }\end{array}$ & Zircon, $\mathrm{ZrSiO}_{4}$ \\
\hline 43 & $\begin{array}{l}\text { Blackish, dark } \\
\text { fragments with } \\
\text { no distinctive features }\end{array}$ & $\begin{array}{c}\text { Oxygen, carbon, } \\
\text { fluorine and REE } \\
\text { elements (La, Ce, Nd) }\end{array}$ & $\begin{array}{l}\text { Parasite } \\
\text { ICDD PDF 47-1832 } \\
\text { and Bastnaesite } \\
\text { ICDD PDF 11-0340 }\end{array}$ & $\begin{array}{c}\text { Bastnaesite, } \mathrm{CeCO}_{3} \mathrm{~F} \\
\text { Parisite, } \mathrm{Ca}(\mathrm{Ce}, \mathrm{La})_{2} \mathrm{~F}_{2}\left(\mathrm{CO}_{3}\right)_{3} \\
\text { Probably a natural blend of the two minerals, } \\
\text { used as standard for REE carbonates. }\end{array}$ \\
\hline 44 & Greyish-green fragments & $\begin{array}{l}\text { Phosphor, oxygen, } \\
\text { thorium, calcium, REE } \\
\text { elements (Ce, La, Nd) }\end{array}$ & $\begin{array}{l}\text { Neodymium phosphate } \\
\text { ICDD PDF 83-0654 }\end{array}$ & Monazite, (Ce,REE) $\mathrm{PO}_{4}$ \\
\hline 45 & Black fragments & Manganese, sulphur & $\begin{array}{c}\text { Alabandite } \\
\text { ICDD PDF 88-2223 }\end{array}$ & Alabandite, (MnS) \\
\hline 46 & $\begin{array}{c}\text { Black fragments, } \\
\text { with fibrous appearance. } \\
\text { Black streak }\end{array}$ & Manganese and oxygen & $\begin{array}{c}\text { Pyrolusite } \\
\text { ICDD PDF 72-1984 }\end{array}$ & Pyrolusite, $\mathrm{MnO}_{2}$ \\
\hline 47 & $\begin{array}{l}\text { Pink fragments } \\
\text { with cleavage traces, } \\
\text { low hardness }\end{array}$ & $\begin{array}{l}\text { Manganese, oxygen, } \\
\text { carbon and a minor } \\
\text { amount of calcium }\end{array}$ & $\begin{array}{l}\text { Rhodochrosite } \\
\text { ICDD PDF 44-1472 }\end{array}$ & Rhodochrosite, $\mathrm{MnCO}_{3}$ \\
\hline 48 & $\begin{array}{l}\text { Pink fragments } \\
\text { without any cleavage }\end{array}$ & $\begin{array}{l}\text { Silicon, oxygen, } \\
\text { manganese and minor } \\
\text { amount of calcium } \\
\text { and magnesium }\end{array}$ & $\begin{array}{l}\text { Rhodonite } \\
\text { ICDD PDF 83-2212 and } \\
\text { Bustamite } \\
\text { ICDD PDF 85-1034 }\end{array}$ & $\begin{array}{l}\text { Rhodonite (magnesian), (Mn, } \mathrm{Mg}) \mathrm{SiO}_{3} \\
\text { Bustamite, (Ca,Mn) } \mathrm{SiO}_{3} \\
\text { Probably a natural mix of the two } \\
\text { Mn-rich silicates Rhodonite and Bustamite }\end{array}$ \\
\hline 49 & Sand & $\begin{array}{l}\text { Oxygen, silicon, sodium, } \\
\text { potassium and calcium }\end{array}$ & $\begin{array}{c}\text { Quartz } \\
\text { ICDD PDF 86-1629 } \\
\text { and Albite } \\
\text { ICDD PDF 09-0466 }\end{array}$ & $\begin{array}{l}\text { Quartz, sodic feldspar, } \\
\text { potassic feldspar } \\
\text { Sand, mainly composed } \\
\text { of Quartz and Feldspars. }\end{array}$ \\
\hline 50 & $\begin{array}{l}\text { Intense yellow } \\
\text { fragments, vitreous, } \\
\text { with some cleavage }\end{array}$ & Zinc, sulphur and iron & $\begin{array}{l}\text { Pyrrothite } \\
\text { ICDD PDF 76-2308 and } \\
\text { Sphalerite } \\
\text { ICDD PDF 77-2100 }\end{array}$ & $\begin{array}{c}\text { Pyrrothite }\left(\mathrm{Fe}_{7} \mathrm{~S}_{8}\right) \\
\text { Sphalerite }(\mathrm{ZnS}) \\
\text { A mix of iron and zinc sulphides }\end{array}$ \\
\hline 51 & $\begin{array}{l}\text { Pale yellowish powder, } \\
\text { with some metallic lustre }\end{array}$ & $\begin{array}{l}\text { Iron, sulphur } \\
\text { and oxygen }\end{array}$ & $\begin{array}{c}\text { Pyrite } \\
\text { ICDD PDF 89-3057 }\end{array}$ & $\begin{array}{l}\text { Pyrite, } \mathrm{FeS}_{2} \\
\text { The sample was probably made } \\
\text { of crushed Pyrite, strongly oxidized } \\
\text { during a century. }\end{array}$ \\
\hline 52 & Black fragments & $\begin{array}{l}\text { Mainly iron and oxygen, } \\
\text { some aluminum and } \\
\text { calcium in small portions }\end{array}$ & $\begin{array}{c}\text { Magnetite } \\
\text { ICDD PDF 88-0315 }\end{array}$ & $\begin{array}{c}\text { Magnetite, } \mathrm{Fe}_{3} \mathrm{O}_{4} \\
\text { Impurities of silicates }\end{array}$ \\
\hline 53 & $\begin{array}{c}\text { Dark reddish } \\
\text { fragments with } \\
\text { fibrous appearance }\end{array}$ & $\begin{array}{l}\text { Iron and oxygen, } \\
\text { minor amount of } \\
\text { aluminum and silicon }\end{array}$ & $\begin{array}{c}\text { Hematite } \\
\text { ICDD PDF 89-0599 }\end{array}$ & Hematite, $\mathrm{Fe}_{2} \mathrm{O}_{3}$ \\
\hline 54 & $\begin{array}{l}\text { Reddish-yellowish } \\
\text { dark fragments, } \\
\text { fibrous appearance }\end{array}$ & Oxygen and iron & $\begin{array}{c}\text { Goethite } \\
\text { ICDD PDF 29-0713 }\end{array}$ & Goethite, $\mathrm{FeO}(\mathrm{OH})$ \\
\hline 55 & $\begin{array}{l}\text { Rhombohedrical shaped } \\
\text { fragment, dark yellow }\end{array}$ & $\begin{array}{l}\text { Iron, oxygen } \\
\text { and carbon }\end{array}$ & $\begin{array}{c}\text { Siderite } \\
\text { ICDD PDF 83-1764 }\end{array}$ & Siderite, $\mathrm{FeCO}_{3}$ \\
\hline 56 & $\begin{array}{l}\text { Grey-greenish fragments } \\
\text { with conchoidal fracture }\end{array}$ & $\begin{array}{l}\text { Iron, phosphor, oxygen } \\
\text { and minor amount of } \\
\text { sodium, aluminium. }\end{array}$ & $\begin{array}{l}\text { Natrodufrenite } \\
\text { ICDD PDF 35-0570 }\end{array}$ & $\begin{array}{l}\text { Vivianite, } \mathrm{Fe}_{3}\left(\mathrm{PO}_{4}\right)_{2} \cdot 8 \mathrm{H}_{2} \mathrm{O} \\
\text { The sample was probably vivianite, } \\
\text { altered in Natrodufrenite }\end{array}$ \\
\hline
\end{tabular}




\section{Continued}

57 White, dusty fragments Iron, arsenic and oxygen.

58

Greenish fragments

Dark grey fragments of metallic lustre

Light grey fragments with metallic lustre

61

A very dark, black powder and fragments

Apple green fragments with crusty appearance

Greyish-black fragment, crystalline

65

66

67

vitreous fragments

Angular blackish

submetallic lustre

White sub-hyaline

68

fragments with

traces of cleavage

Blackish crystalline

69

fragments with good

pseudo-cubic cleavage

70

Black fragments without cleavage and minor amount of

Manganese and oxygen, small amount of calcium

Zinc, oxygen and carbon

Sulphur, antimony and

Hyaline whitish fragments Lead, phosphor, oxygen

71 with cleavage traces and natural flat surfaces

72

White fragments

Orange crystalline fragments

Brown-reddish crystalline fragments

Elongated steel-greyish fragments
Iron, sulphur and

oxygen, with sodium

as minor element

Sulphur and antimony

Arsenic, nickel, cobalt sulphur and iron and magnesium

Nickel and oxygen, with small

amount of arsenic

Nickel and arsenic

Nickel, antimony, sulphur, arsenic

Sulphur and zinc

Sulphur, zinc and minor iron

Lead and sulphur minor iron

Scorodite

ICDD PDF 37-0468

Copiapite

ICDD PDF 71-1546 and

sodium iron sulfate

ICDD PDF 29-1218

Stibnite

ICDD PDF 74-1046

Skutterudite

ICDD PDF 25-0118

The spectrum shows a very low degree

of crystallinity.

The spectrum

shows a very low degree of crystallinity.

Nickeline

ICDD PDF 75-0603

Ulmannite

ICDD PDF 83-1221

Sphalerite ICDD PDF 65-0309

Ferroan Sphalerite ICDD PDF 89-4938

Smithsonite ICDD PDF 83-1765

Galena

ICDD PDF 65-0135

Berthierite

ICDD PDF 24-0509 Iron sulphide

ICDD PDF 65-1211

Iron sulfate

ICDD PDF 73-1057

Pyromorphite

ICDD PDF 73-1729 calcium,

\section{Lead, oxygen} and carbon

Lead, chromium and oxygen

Tin and oxygen

Bismuth and sulphur
Cerussite

ICDD PDF 76-2056

Crocoite

ICDD PDF 73-1332

Cassiterite

ICDD PDF 77-0447

Bismutinite ICDD PDF 65-3884
Scorodite, $\mathrm{FeAsO}_{4} \cdot 2 \mathrm{H}_{2} \mathrm{O}$

Copiapite, $\mathrm{Fe}_{5}\left(\mathrm{SO}_{4}\right)_{6}(\mathrm{OH})_{2} \cdot 20 \mathrm{H}_{2} \mathrm{O}$ sodium iron sulphate, $\mathrm{Na}_{6} \mathrm{Fe}\left(\mathrm{SO}_{4}\right)_{4}$ Original sample was Copiapite, slightly altered with formation of iron sulphates

Stibnite, $\mathrm{Sb}_{2} \mathrm{~S}_{3}$

Ni-Skutterudite, $(\mathrm{Co}, \mathrm{Ni}, \mathrm{Fe}) \mathrm{As}_{3}$

WAD ("Psilomelane")

A mix of manganese oxide

Nepouite

The sample is the Ni homologous of Chrysocolla, a mix of various Ni-silicate with different hydration degree and low crystallinity, deriving from Ni-sulphide alteration

Nickeline, NiAs

As-Ulmannite, NiSbS

Sphalerite, ZnS

Iron-rich sphalerite, (Zn,Fe)S

The iron rich variety of sphalerite often known as "marmatite"

Smithsonite, $\mathrm{ZnCO}_{3}$

Galena, $\mathrm{PbS}$

Berthierite, $\mathrm{FeSb}_{2} \mathrm{~S}_{4}$ A mixing of Berthierite and minor Pyrite, oxidized during time

Pyromorphite, $\mathrm{Pb}_{5}\left(\mathrm{PO}_{4}\right)_{3} \mathrm{Cl}$

Cerussite, $\mathrm{PbCO}_{3}$

Crocoite, $\mathrm{PbCrO}_{4}$

Cassiterite, $\mathrm{SnO}$

Bismutinite, $\mathrm{Sb}_{2} \mathrm{~S}_{3}$ 


\section{Continued}

\begin{tabular}{|c|c|c|c|c|}
\hline 77 & Blackish fragments & $\begin{array}{l}\text { Uranium, oxygen, and } \\
\text { minor calcium, silicon } \\
\text { and iron }\end{array}$ & $\begin{array}{c}\text { Uraninite } \\
\text { ICDD PDF 47-1879 }\end{array}$ & Uraninite, $\mathrm{UO}_{2}$ \\
\hline 78 & Black lustre fragments & Copper and sulphur & $\begin{array}{c}\text { Chalcocite } \\
\text { ICDD PDF 33-0490 }\end{array}$ & $\begin{array}{l}\text { Chalcocite, } \mathrm{Cu}_{2} \mathrm{~S} \\
\text { Quartz-impure chalcocite }\end{array}$ \\
\hline 79 & Blackish fragments & $\begin{array}{l}\text { Copper, antimony and } \\
\text { sulphur }\end{array}$ & $\begin{array}{c}\text { Tetrahedrite } \\
\text { ICDD PDF 42-0561 }\end{array}$ & $\begin{array}{l}\text { Tetrahedryte, } \mathrm{Cu}_{12} \mathrm{Sb}_{4} \mathrm{~S}_{13} \\
\text { The sample also contains pyrite } \\
\text { and iron/copper oxides }\end{array}$ \\
\hline 80 & $\begin{array}{l}\text { Greenish black fragments } \\
\text { with alterations }\end{array}$ & $\begin{array}{c}\text { Copper, sulphur, iron and } \\
\text { oxygen }\end{array}$ & $\begin{array}{c}\text { Chalcopyrite } \\
\text { ICDD PDF 83-0983 }\end{array}$ & $\begin{array}{l}\text { Chalcopyrite, } \mathrm{CuFeS}_{2} \\
\text { The sample shows alteration } \\
\text { and oxidation of the surface }\end{array}$ \\
\hline 81 & Dark, reddish fragments & Copper and oxygen & $\begin{array}{c}\text { Cuprite } \\
\text { ICDD PDF 78-2076 }\end{array}$ & Cuprite, $\mathrm{Cu}_{2} \mathrm{O}$ \\
\hline 82 & $\begin{array}{l}\text { Reddish fragments with } \\
\text { deep green little crystals }\end{array}$ & $\begin{array}{l}\text { Sulphur, oxygen } \\
\text { and copper }\end{array}$ & $\begin{array}{c}\text { Brochantite } \\
\text { ICDD PDF 43-1458 }\end{array}$ & Brochantite, $\mathrm{Cu}_{4}\left(\mathrm{SO}_{4}\right)_{2}(\mathrm{OH})_{6}$ \\
\hline 83 & $\begin{array}{l}\text { Green earthy fragments } \\
\text { with traces of cleavage }\end{array}$ & $\begin{array}{l}\text { Copper, oxygen } \\
\text { and carbon }\end{array}$ & $\begin{array}{c}\text { Malachite } \\
\text { ICDD PDF 41-1390 }\end{array}$ & Malachite, $\mathrm{Cu}_{2}\left(\mathrm{CO}_{3}\right)(\mathrm{OH})_{2}$ \\
\hline 84 & $\begin{array}{l}\text { Earthy light } \\
\text { blue fragments }\end{array}$ & $\begin{array}{l}\text { Silicon, oxygen, copper } \\
\text { and calcium as trace } \\
\text { element }\end{array}$ & $\begin{array}{c}\text { Malachite } \\
\text { ICDD PDF 41-1390 }\end{array}$ & $\begin{array}{c}\text { Malachite, } \mathrm{Cu}_{2}\left(\mathrm{CO}_{3}\right)(\mathrm{OH})_{2} \\
\text { Chrysocolla }\end{array}$ \\
\hline 85 & $\begin{array}{l}\text { Red globular } \\
\text { fragments }\end{array}$ & Mercury and sulphur & $\begin{array}{c}\text { Cinnabar } \\
\text { ICDD PDF 89-0438 }\end{array}$ & $\begin{array}{c}\text { Cinnabar, HgS } \\
\text { Small globular aggregates of } \\
\text { Cinnabar in clay matrix }\end{array}$ \\
\hline 86 & $\begin{array}{l}\text { Blackish, earthy } \\
\text { mass with no cleavage }\end{array}$ & $\begin{array}{l}\text { Sulphur, antimony, } \\
\text { copper and zinc, } \\
\text { minor arsenic and iron }\end{array}$ & $\begin{array}{c}\text { Tetrahedrite } \\
\text { ICDD PDF 88-0282 }\end{array}$ & $\begin{array}{l}\text { Tetrahedrite, } \mathrm{Cu}_{12} \mathrm{Sb}_{4} \mathrm{~S}_{13} \\
\text { Tetrahedryte with a little amount of } \\
\mathrm{S} \text { and } \mathrm{Zn} \text { as vicariant of } \mathrm{Sb} \\
\text { and } \mathrm{Cu} \text { respectively }\end{array}$ \\
\hline 87 & $\begin{array}{l}\text { Whitish-green } \\
\text { ductile fragments }\end{array}$ & Silver and chlorine & $\begin{array}{c}\text { Chlorargirite } \\
\text { ICDD PDF 01-1031 }\end{array}$ & Chlorargirite, AgCl \\
\hline 88 & $\begin{array}{l}\text { Small silvery filamentous } \\
\text { fragments }\end{array}$ & $\begin{array}{c}\text { Silver and small } \\
\text { amount of oxygen. }\end{array}$ & $\begin{array}{c}\text { Silver } \\
\text { ICDD PDF 03-0921 }\end{array}$ & Silver, Ag \\
\hline 89 & $\begin{array}{l}\text { Ductile steel-grey } \\
\text { fragments }\end{array}$ & $\begin{array}{l}\text { Silver and sulphur, } \\
\text { with a small } \\
\text { amount of oxygen }\end{array}$ & $\begin{array}{c}\text { Acanthite } \\
\text { ICDD PDF 14-0072 }\end{array}$ & $\begin{array}{c}\text { Acanthite, } \mathrm{Ag}_{2} \mathrm{~S} \\
\text { The small amount of identified oxygen } \\
\text { is probably due to surface oxidation }\end{array}$ \\
\hline 90 & $\begin{array}{l}\text { Blackish fragments with } \\
\text { deep red tinge }\end{array}$ & $\begin{array}{l}\text { Silver, sulphur and } \\
\text { antimony }\end{array}$ & $\begin{array}{c}\text { Pyrargiryte } \\
\text { ICDD PDF 77-0329 }\end{array}$ & Pyrargyrite, $\mathrm{Ag}_{3} \mathrm{SbS}_{3}$ \\
\hline 91 & $\begin{array}{l}\text { Pitch black fragments } \\
\text { with conchoidal fracture }\end{array}$ & $\begin{array}{l}\text { Niobium, oxygen, iron, } \\
\text { manganese and } \\
\text { minor tantalum, } \\
\text { uranium and titanium }\end{array}$ & $\begin{array}{c}\text { Columbite } \\
\text { ICDD PDF 84-1020 }\end{array}$ & Columbite, $\mathrm{FeNb}_{2} \mathrm{O}_{6}$ \\
\hline 92 & $\begin{array}{l}\text { Blackish-brownish } \\
\text { fragments }\end{array}$ & Oxygen and titanium & $\begin{array}{c}\text { Rutile } \\
\text { ICDD PDF 87-0710 }\end{array}$ & Rutile, $\mathrm{TiO}_{2}$ \\
\hline 93 & Black pitchy fragments & $\begin{array}{l}\text { Iron, titanium } \\
\text { and oxygen }\end{array}$ & $\begin{array}{c}\text { Ilmenite } \\
\text { ICDD PDF 75-1210 }\end{array}$ & Ilmenite, $\mathrm{FeTiO}_{3}$ \\
\hline 94 & $\begin{array}{l}\text { Steel grey fragments } \\
\text { with traces of cleavage }\end{array}$ & Sulphur and antimony & $\begin{array}{c}\text { Stibnite } \\
\text { ICDD PDF 74-1046 }\end{array}$ & Stibnite, $\mathrm{Sb}_{2} \mathrm{~S}_{3}$ \\
\hline 95 & $\begin{array}{l}\text { Steel grey fragments } \\
\text { with good cleavage }\end{array}$ & $\begin{array}{l}\text { Calcium, oxygen, } \\
\text { tungsten and iron }\end{array}$ & $\begin{array}{c}\text { Hubnerite } \\
\text { ICDD PDF 12-0727 }\end{array}$ & $\begin{array}{c}\text { Hubnerite, }(\mathrm{Fe}, \mathrm{Mn}) \mathrm{WO}_{4} \\
\text { Scheelite, } \mathrm{CaWO}_{4} \\
\text { Mn-poor Hubnerite and traces of Scheelite }\end{array}$ \\
\hline 96 & $\begin{array}{l}\text { Pale yellow fragments } \\
\text { with good cleavage }\end{array}$ & $\begin{array}{c}\text { Calcium, } \\
\text { oxygen, tungsten }\end{array}$ & $\begin{array}{c}\text { Scheelite } \\
\text { ICDD PDF 41-1431 }\end{array}$ & Scheelite, $\mathrm{CaWO}_{4}$ \\
\hline 97 & Silvery plates, flexible & $\begin{array}{l}\text { Molybdenum } \\
\text { and sulphur }\end{array}$ & $\begin{array}{c}\text { Molybdenite } \\
\text { ICDD PDF 65-3656 }\end{array}$ & Molybdenite, $\mathrm{MoS}_{2}$ \\
\hline 98 & $\begin{array}{l}\text { Yellow orange } \\
\text { small crystals }\end{array}$ & $\begin{array}{l}\text { Lead, molybdenum } \\
\text { and oxygen }\end{array}$ & $\begin{array}{c}\text { Wulfenite } \\
\text { ICDD PDF 74-1075 }\end{array}$ & Wulfenite, $\mathrm{PbMoO}_{4}$ \\
\hline
\end{tabular}




\begin{tabular}{|c|c|c|c|c|}
\hline 99 & $\begin{array}{l}\text { Greenish black fragments, } \\
\text { no trace of cleavage }\end{array}$ & $\begin{array}{l}\text { Chromium, oxygen, } \\
\text { magnesium, } \\
\text { aluminium and iron }\end{array}$ & $\begin{array}{l}\text { Ferroan-magnesiochromite } \\
\text { spinel } \\
\text { ICDD PDF 09-0353 }\end{array}$ & $\begin{array}{l}\text { Spinel (magnesiochromite, ferroan) } \\
(\mathbf{M g}, \mathbf{F e})(\mathbf{C r}, \mathbf{A l})_{2} \mathbf{O}_{4}\end{array}$ \\
\hline 100 & Grey dusty fragments & $\begin{array}{l}\text { Arsenic, with small } \\
\text { amount of oxygen and } \\
\text { antimony }\end{array}$ & $\begin{array}{c}\text { Arsenic } \\
\text { ICDD PDF 72-1048 }\end{array}$ & $\begin{array}{c}\text { Arsenic, As } \\
\text { Probably altered on surface with formation } \\
\text { of trivalent arsenic oxide (Arsenolite) }\end{array}$ \\
\hline 101 & $\begin{array}{l}\text { Orange reddish crystals, } \\
\text { with vivid lustre }\end{array}$ & Sulphur and arsenic & $\begin{array}{c}\text { Realgar } \\
\text { ICDD PDF 71-2434 }\end{array}$ & Realgar, AsS \\
\hline 102 & $\begin{array}{l}\text { Yellow brownish } \\
\text { light fragments, } \\
\text { rounded aspect }\end{array}$ & Carbon & Amorphous & $\begin{array}{c}\text { Amber } \\
\text { The identification was obtained also } \\
\text { by mean of combustion test }\end{array}$ \\
\hline 103 & $\begin{array}{l}\text { Yellowish-brownish } \\
\text { granules, very soft }\end{array}$ & Carbon, oxygen & Amorphous & $\begin{array}{l}\text { Beeswax } \\
\text { Final identification has been obtained } \\
\text { with combustion and fusion test. } \\
\text { The mass was contaminated by different } \\
\text { substances (Feldspar, Galena and others) }\end{array}$ \\
\hline 104 & White small scales & Oxygen & $\begin{array}{c}\text { Boric acid } \\
\text { ICDD PDF 30-0199 }\end{array}$ & $\begin{array}{l}\text { Boric acid (sassolite), } \mathrm{H}_{3} \mathrm{BO}_{3} \\
\text { May be either a natural mineral } \\
\text { or a laboratory product. }\end{array}$ \\
\hline 105 & $\begin{array}{l}\text { Vitreous greenish black } \\
\text { fragment with } \\
\text { conchoidal fracture }\end{array}$ & $\begin{array}{l}\text { Silicon, aluminium, } \\
\text { oxygen, magnesium, } \\
\text { sodium, iron } \\
\text { with some titanium }\end{array}$ & $\begin{array}{c}\text { Dravite } \\
\text { (tourmaline group) } \\
\text { ICDD PDF 85-1816 }\end{array}$ & $\begin{array}{l}\text { Dravite (tourmaline group) } \\
\mathrm{NaMg}_{3} \mathrm{Al}_{6}\left(\mathrm{BO}_{3}\right)_{3} \mathrm{Si}_{6} \mathrm{O}_{18}(\mathrm{OH})_{4}\end{array}$ \\
\hline 106 & $\begin{array}{l}\text { Vitreous greenish } \\
\text { grey fragments }\end{array}$ & $\begin{array}{l}\text { Silicon, aluminium, } \\
\text { calcium, magnesium, iron } \\
\text { and manganese }\end{array}$ & $\begin{array}{c}\text { Axinite } \\
\text { ICDD PDF 29-0344 }\end{array}$ & $\begin{array}{c}\text { Mg-axinite } \\
\mathrm{Ca}_{2}\left(\mathrm{Fe}^{2+}, \mathrm{Mg}, \mathrm{Mn}^{2+}\right) \mathrm{Al}_{2} \mathrm{BO}_{3} \mathrm{Si}_{4} \mathrm{O}_{12}(\mathrm{OH})\end{array}$ \\
\hline 107 & White powder & $\begin{array}{l}\text { Magnesium, } \\
\text { chlorine and oxygen }\end{array}$ & $\begin{array}{l}\text { Magnesium } \\
\text { chloroborate } \\
\text { ICDD PDF 85-0899 }\end{array}$ & $\begin{array}{l}\text { Magnesium chloroborate } \\
\qquad \mathrm{ClMg}_{3} \mathrm{~B}_{7} \mathrm{O}_{13} \\
\text { Probably a laboratory product }\end{array}$ \\
\hline 108 & $\begin{array}{l}\text { Transparent, colourless } \\
\text { vitreous fragments }\end{array}$ & Silicon, oxygen & $\begin{array}{c}\text { Quartz } \\
\text { ICDD PDF 86-1629 }\end{array}$ & Quartz, $\mathrm{SiO}_{2}$ \\
\hline
\end{tabular}

\section{Conclusions}

On the other hand, it has not been possible to determine the manufacturing date and origin even if the probetubes' type, the box design and its wood kind suggest a German builder and a period around the second half of XIX century.

The general features of the wooden box show that it is designed either for being carried out during mineralogical missions or for didactic purposes. These didactic-scientific collections have played in their time a fundamental role for largely improving the chemical, geological and mineralogical level of knowledge just before and during the important period of the so-called industrial revolution. Many data are going to be collected about similar collections (private and public) in order to characterize the importance of some mineralogical species, which can be considered as reference terms for the industrial development.

The whole set shows a good correspondence with the description of mineralogical and didactical collections and kits described in several old advertising brochures and catalogues, issued by companies who, since the mid '800, started designing and selling scientific and technological tools and equipment: the German Krantz, based in Bonn and Hugershoff, based in Leipzig or Gregory \& Bottley, based in London. In particular, most these companies built up and supplied their educational collections, like the wooden box, examined in this study, consisting of a minimum of 50 to a maximum of about 170/200 different mineralogical and/or chemical samples each. Just to get an economical evaluation of the wooden box of the present study, a similar one containing 105 samples arranged according Kobell system was costing around 30.00 D.M. after having been quoted by the Franz Hugershoff's catalogue of 1911.

A countertype of the same box (104 fragments of minerals in neat case for blowpipe analysis) was offered in 1936 by the firm Gregory \& Bottley at a price of around $1.5 £$. Today, the approximate and estimated current prize of both boxes would be between 450 and $750 €$. 


\section{References}

[1] Tomalino, M.U. (2011) Una storia della Mineralogia. Ex Libri Mineralia, Torino, 389 p

[2] von Kobell, F. (1862) Geschichte der Mineralogie. Cottaschen Buchhandlung, Munich, 703 p

[3] Bartholinus, E. (1669) Experimenta Crystalli Islandici Disdiaclastici. Danielis Paulli, Hafniae, 60 p.

[4] Cramer, J.A. (1737) Elementa artis docimasticae. Conradum Wishoff and Georg Jac. Wishoff, Leiden, 420 p.

[5] Swab, A. (1748) Bericht uber einem gediegenen Regulus Antimonii oder Spissglanzkonige. Abhandlung der schwedischen Akademie der Wissenschaften, 20, 269.

[6] Cronstedt, A.F. (1756) Beschreibung und untersuchung einer unbekannten Bergart, Zheolites gennant. Abhandlung der schwedischen Akademie der Wissenschaften, 18, 111-113

[7] Cronstedt, A.F. (1758) Forsok til Mineralogie, eller Mineralrikets Upstallning. Trycht hos, Stockholm, 251.

[8] Engestrom, G. (1773) Versuche mit vorerwahntem Salze oder Kien. Abhandlung der schwedischen Akademie der Wissenschaften, 34, 167.

[9] Bergman, T. (1779) Commentatio de Tubo Ferruminatorio. Ioann. Pavl. Kravs, Wien, 60 p. Wright and Wright, W. (1906) Flying-Machine. US Patent No. 821393.

[10] Berzelius, J.J. (1821) Anwendung des Lothrohrs in der Chemie und Mineralogie ubersetzt. Joh. Leonhard Schrag, Nurberg, $311 \mathrm{p}$.

[11] Turner, E. (1825) On the Detection of Boric Acid in Minerals by the Blowpipe. Edinburgh Philosophical Journal, 14, 124.

[12] Plattner, K.F. (1835) Probirkunst mit dem Lothrohr. Johann Ambrosius Barth, Leipzig, 358.

[13] Bunsen, R. (1859) Lothrohrversuche. Liebigs Annalen der Chemie, 111, 3. http://dx.doi.org/10.1002/jlac.18591110302

[14] Kirchhoff, G. and Bunsen R. (1861) Chemische Untersuchungen durk Spektralbeobechtungen. Annalen der Physik, 113, 337-381. http://dx.doi.org/10.1002/andp.18611890702 